\title{
Building Yugoslavia in the Sand? Dalmatian Refugees in Egypt, 1944-1946
}

\author{
Florian Bieber
}

"In front of us, the task is to build and complete the peoples' government in exile."

Mate Barbić, 27.11.44. ${ }^{1}$

$30^{\circ} 02^{\prime} 10.2^{\prime \prime} \mathrm{N}, 32^{\circ} 36^{\prime} 47.9^{\prime \prime} \mathrm{E}$. A star marks the spot. In the desert east of the Suez Canal, some ten kilometers northeast of the Egyptian city of Suez, a fivepointed star is visible from space. The cemetery in the shape of a Partisan five-pointed star (petokraka) is the only visible reminder in Egypt of 30,000 Yugoslavs who found refuge here during the two years at the cusp of World War Two and the early post-war period, between 1944 and 1946. ${ }^{2}$ The refugees, mostly from Dalmatia, had fled Nazi occupation of the Dalmatian coast following the Italian surrender in September 1943 with the help of the British navy and the Yugoslav partisans. ${ }^{3}$ They first made their way to southern Italy and later to Egypt. Most found temporary shelter in El Shatt, a former British Army camp prepared to defend Egypt from the Axis campaign in north Africa.

Draft versions were presented at the 2017 ASEEES convention in Chicago and the 2017 Brownbag Seminar of the Center for Southeast European Studies, University of Graz. I would like to thank Mateo Bratanić for comments on a draft version of the article. The research for this article mostly draws on the UN archives in New York (UNA), the United Nations Relief and Rehabilitation Administration (UNRRA) that managed the camps from May 1, 1944, and the Državni arhiv u Splitu (Croatian State Archives in Split) (HR-DAST), which hosts most materials of the Central Refugee Committee (Centralni odbor zbjega), the Partisan control organization that managed the camps. Some materials from the National Archives (London) have also been consulted.

1. HR-DAST 23-442, Izvještaj, Mate Barbić, November 27, 1944.

2. This article uses the terminology employed by the UNRRA, British camp management, and the Yugoslav-led camp management. All described the refugees as Yugoslav, emphasizing the mutual commitment to reestablish the state that had been destroyed by the Axis powers in 1941, which the Partisans sought to resurrect. The other regional signifier used is Dalmatians, reflecting their strong regional identity. The refugees were identified as both Croats and Serbs, although the vast majority were Catholic Croats.

3. The Partisan movement was officially known as People's Liberation Movement (Narodnooslobodilački pokret, NOP), and was dominated by the Communist Party (Komunistička partija Jugoslavije, KPJ), but included individuals with a broad range of political backgrounds.

Slavic Review 79, no. 2 (Summer 2020)

(C) The Author(s), 2020. Published by Cambridge University Press on behalf of the Association for Slavic, East European, and Eurasian Studies. This is an Open Access article, distributed under the terms of the Creative Commons Attribution licence (http://creativecommons.org/ licenses/by/4.0/), which permits unrestricted re-use, distribution, and reproduction in any medium, provided the original work is properly cited.

doi: 10.1017/slr.2020.85 
Once German and Italian forces were routed at El Alamein in November 1942, the threat receded, and the camps became available for refugees as British troops relocated to Europe. El Shatt, in sight of the Suez Canal, was a desolate place in the desert. The high temperatures during the day and the cold at night, together with harsh winds, made it an unlikely home.

These refugees are among many Europeans who found shelter in the Middle East during the war: Greeks, who fled the Dodecanese and Aegean islands via Turkey to Allied-controlled Syria, Lebanon and Palestine, and Poles, mostly part of the army formed of prisoners of war released in the Soviet Union after the German invasion of $1941 .{ }^{4}$ They all were just a small part of the millions who moved, either voluntarily or by force, during the war and in its immediate aftermath. Of those millions, many, if not most, experienced camps, the ubiquitous symbol of the war. Camps varied in terms of the goals of those who built them, and the experiences of those who found themselves in them. From the horrors of Nazi death camps to concentration and forced labor camps, these included prisoner of war camps and camps for the displaced.

The experience of the Yugoslav refugees highlights an important and neglected episode in the creation of the socialist Yugoslav state. Camps are a site were individuals encounter state authority in a more structured and intense manner than in other contexts. In this case, it is between refugees and the newly-emerging Socialist Yugoslav state that offers insight into the post war order. In addition, this experience also demonstrates that refugees were not just passive subjects of host countries' policies and the aid organizations that supported them, but actively pursued their post-war goals, either to return in conjunction with the emerging Partisan authorities or alternatively by rejecting the Partisans. Returning agency is particularly significant at a time when debates about refugees are shaped by fear, with refugees often reduced to objects of debates and policies. ${ }^{5}$

The history of the Yugoslavs in Egypt belongs to one of the more benign camp experiences of the twentieth century. While conditions were harsh, the Allies' aim was to care for the refugees rather than incarcerate them, or worse. Unlike millions of others, the Yugoslavs could, and mostly did, return home. As this aspect of Europe's history of displacement was episodic, it has largely been forgotten in Yugoslav, Croatian, and European historiography. The reasons for the neglect in Yugoslav historiography were twofold: first, the plight of the refugees paled in comparison with the repression of those who stayed at home by German occupying troops and the Partisan struggle, which attracted the bulk of the attention from socialist Yugoslav World War Two historiography. Second, the predominance of women and children among the refugees did not fit the male-dominated historiography of the heroic resistance struggle. ${ }^{6}$ In post-1991

4. Recent historiography on the war time experience of Greeks and Poles gives little attention to the significant number of refugees in the Middle East. See Halik Kochanski, The Eagle Unbowed: Poland and the Poles in the Second World War (Cambridge, Mass., 2012); David Brewer, Greece, the Decade at War: Occupation, Resistance and Civil War (London, 2016).

5. Philipp Ther, The Outsiders: Refugees in Europe since 1492, trans. Jeremiah Riemer (Princeton, 2019).

6. In May 1944, of the 23,663 refugees in Egypt, 19.2 percent were men, 34.1 percent women and 46.7 percent children. UN Archives (UNA), S-0520-0298, Population at Camps, 
Croatia, the experience fits even less into the national historiography. The refugees were overwhelmingly supporters of the Partisans, and the Yugoslav project stood at the center of camp life. Thus, this episode was ignored and forgotten, just as the graveyard of the refugees who perished in the camps was neglected. Renewed interest emerged only after the peak of Croatian nation-building, with greater space for critical historiography in the mid-2000s. ${ }^{7}$

Research on the broader European experience of displacement and the plight of refugees at the end of the war and the immediate post-war period has experienced renewed interest recently, not least because of the public attention devoted to refugees from the Middle East in Europe. ${ }^{8}$ Yet the displacement of Europeans to Africa received little attention, mostly because the refugees came from the European periphery and fled outside Europe.

The two years in the Egyptian desert were not only significant for the refugees' experiences but also became a crucial site for experimenting with Yugoslav ideas and building institutions. ${ }^{9}$ In addition, their experience was ultimately transnational, as they interacted with the British authorities, numerous American volunteers from different aid organizations, Egyptians, and other refugees (mostly Greek), as well as Jews who fled with the Dalmatians from Nazi occupation but then quickly sought to leave for Palestine. They wrote to their relatives back home in Yugoslavia, but also sought help, invitations, and consolation from their kin in New Zealand, Australia, Latin America, and the United States. As a result, their story is part of the wider transnational refugee experience. ${ }^{10}$

What set the Yugoslav refugees apart from the millions of other refugees was the extent to which their country of origin organized their lives and integrated refugee life into the state-building experience. As such, the future state became the main interlocutor for the refugees and the allied authorities at the camps. Most refugees fell into three patterns. Some had fled from their country of origin due to the repressive policies of their government, such as the Jews who fled Nazi Germany. Of these, some fled to countries that would welcome them, at least at first. Others countries, such as Italy, would protect

May 23, 1944. Josip Piva, ed., Prosvjetno-kulturna djelatnost zbjega u El Šatu 1944-1945 (Zagreb, 1980); Dušan Plenča, “Jugoslavenski zbjeg u Italiji i Egiptu,” Istorija radničkog pokreta, Vol. 4 (Beograd, 1967), 335-477; Danica Nola, El Shatt (Zagreb, 1988).

7. An influential exhibition of the Croatian Historical Museum, the publication of new memoirs, the renewal of the graveyard in El Shatt, and several academic studies have ended the forgetfulness and neglect. Nataša Mataušić, ed., El shatt. Zbjeg iz hrvatske u pustinji Sinaja, Egipat (1944-1946) (Zagreb, 2007). Mateo Bratanić, Hrvatski zbjegovi u Egipat 1943-1946, (PhD diss., University of Zadar, 2009), and Kornelija Ajlec, "Egipatska vlada i rješavanje izbjegličke problematike tijekom Drugoga svjetskog rata," Časopis za suvremenu povijest 46, no. 2 (2014), 295-318.

8. Tara Zahra, The Lost Children: Reconstructing Europe's Families after World War II (Cambridge, Mass., 2011), Ben Shephard, The Long Road Home: The Aftermath of the Second World War (London, 2011).

9. In Socialist Yugoslavia, the main Dalmatian daily Slobodna Dalmacija reported on the camps, although interest faded in reporting during the 1950s with merely a few articles over several years. Interest revived in the late 1980s, including longer reportages and the co-organization of charter flights to Egypt for former refugees and their relatives in 1987 and 1988.

10. Peter Gatrell, The Making of the Modern Refugee (Oxford, 2013). 
refugees from Nazi concentration camps, but they would remain potentially vulnerable due to the German-Italian alliance.

Other refugees fled with their governments that were displaced by the occupying forces, mostly Germany and its allies. This group included Greek and Polish refugees in the Middle East and Africa who were supported by the Greek and Polish governments in exile in Cairo and London, respectively. These governments in exile were weak and were themselves displaced, possessing limited resources and infrastructure. While west European governments in exile would return victorious after the war, most central and eastern European governments did not resume authority at the end of the war.

The Yugoslav experience falls within a distinct pattern, where the emerging government organized the evacuation, maintained strong organizational ties with the refugees, and engaged in state-building among the refugee community in preparation for their return home. There are few comparable cases, as governments were unable or unwilling to exert a similar degree of authority over their citizens in exile.

For the Partisans, it was also a crucial moment to consolidate their ties with their western allies. This included the British Army, which guarded the camp and provided supplies; British and American volunteers-mostly from religious organizations ${ }^{11}$-and the Allied administration of the United Nations Relief and Rehabilitation Administration (UNRRA), which had taken over from the British Army in May $1944 .^{12}$ Thus, the Partisans had to negotiate their relationship with their western allies, and the episode in Egypt highlights the great lengths to which the Partisan camp administration went to convince its allies of the socialist Yugoslav project. Until 1943, the British government primarily supported King Petar II and the Yugoslav government in exile, as well as the monarchist Četnik forces in Yugoslavia. Part of the government in exile, including ministers and officers of the royal army, were based in Cairo. ${ }^{13}$ While the Dalmatians were being displaced, British support began to shift. They offered more support to the Partisans, whom they judged to be more effective and reliable. The evacuation of the Dalmatian refugees, with British assistance, to Egypt would be a test case for the emerging alliance. For the communist-led partisans, a good relationship with Britain, the most important source of Allied military support and recognition, was essential. Thus, in addition to maintaining control and molding the refugees into Yugoslav

11. Friends' Ambulance Unit, The Order of St. John, the British Red Cross, Save the Children, the American Friends' Service Committee. See Jessica Reinisch, "Introduction: Relief in the Aftermath of War," Journal of Contemporary History 43, no. 3 (July 2008): 371404; Johannes-Dieter Steinert, "British Humanitarian Assistance: Wartime Planning and Postwar Realities," Journal of Contemporary History 43, no. 3 (July 2008): 421-35. Lewis M. Hoskins, "Voluntary Agencies and Foundations in International Aid," The ANNALS of the American Academy of Political and Social Science 329, no. 1 (May 1960): 57-68.

12. UNRRA came into existence in November 1943, two years before the United Nations itself, and was a US-led effort to provide relief for refugees and prepare for the post-war rehabilitation of Europe. Jessica Reinisch, "Internationalism in Relief: The Birth (and Death) of UNRRA," Past and Present 210, Supplement 6 (2011): 258-89.

13. The government and the king initially fled to London in 1941. In 1943 the government in exile under Prime Minister Božidar Purić relocated to Cairo, whereas King Petar II remained in London. 
citizens, the Partisans sought to demonstrate their ability to manage the displacement. The Refugee Central Committee (Centralni odbor Zbjega, COZ) had to negotiate with the UNRRA and their British and American allies, who ran and supplied the camps. Tensions were inevitable, as the Partisan movement and the British viewed each other with some skepticism in light of their ideological differences. Their relations were marked by both mutual admiration and suspicion that foreshadowed the Cold War. This mirrored the cooperation between the British and the Partisans elsewhere, including in maintaining control over the island of Vis to serve as headquarters for Tito and to supply the Partisan army. It also showed that the Yugoslavs were able to work and cooperate with western partners, which would become the norm after the Tito-Stalin split in 1948, just two years after the closure of the camps.

The defining feature of the Partisan camp administration was their degree of control and influence. This gave the refugees a sense of purpose and motivation for their return and injected an element of self-management, control, and ideological indoctrination. Camp life in El Shatt was one of the first experiments in state-building by the Partisan movement. It had controlled liberated territories in Yugoslavia, starting with the "Užička Republika" in southwestern Serbia in the fall of 1941 and spreading to large swathes of land in Bosnia and Croatia in the subsequent years, but these were short-lived and in flux. It established Peoples' Councils in liberated areas, and these gradually evolved into the seeds of future Communist Party-led government. ${ }^{14}$ In the Egyptian desert, the Partisans could build institutions and convince a captive audience of the merits of its cause. These included schools, newspapers, and establishing a new social contract, from gender relations to labor.

In the two years between early 1944 and 1946, the Yugoslav camps in Egypt became a microcosm of early Yugoslav state-building, the negotiation of relations between the Partisans and the western Allies, and calibrating the tools of control, consent, and repression among their people. This story of the camps and their inhabitants thus constitutes a bridge between the war and the post-war period, helping to understand the rise of Socialist Yugoslavia. It also seeks to draw attention to European refugees whose experience differed significantly from most of the millions scattered across Europe.

\section{Arrival and Camp Life}

The refugees arrived in Egypt after a long, arduous journey. Following the armistice of Fascist Italy with the Allies on September 3, 1943, Partisan forces were able to take control of large swathes of the Yugoslav coast previously held by Italian forces. These included the city of Spilt and most islands in central Dalmatia. The Partisan victory turned out to be short-lived, however. German units quickly began taking over, motivated by the fear of an Allied invasion of the Balkans. Over the fall and winter of 1943-1944, German army

14. By late 1942, the partisans had managed to establish some 1,477 National Liberation Councils (NOO), including in towns under control of the Independent State of Croatia. This number grew to 4,456 by 1943 . Hodimir Sirotković, "Stvaranje federalne Hrvatske u narodnooslobodilačkoj borbi," Časopis za suvremenu povijest 3 no. 2-3 (1971), 23, 28. 
units occupied the Dalmatian coast, forcing a growing group of refugees to move towards Vis, one of the islands furthest out into the Adriatic. The refugees included communist sympathizers and partisans, with their families, but also others who feared German reprisals.

In November 1943, the Partisans created the COZ in the small fishing village of Vrboska on the island of Hvar among those being displaced by the German advance. It also included other opponents of the Ustaša regime and incorporated key mass organizations, such as the Antifascist Women's Front (Antifašistički front žena, AFŽ) and the youth movement (Ujedinjeni savez antifašističke omladine Jugoslavije, USAO). Being responsible for governing the refugees while they were displaced, it was organized into administrative sections dealing with issues such as education, health care, and culture.

The last stop in Yugoslavia for refugees was Vis: the island was held by the Partisans, with British military assistance, throughout the war. As the island was transformed from a sleepy fishing community in the middle of the Adriatic to a military outpost to defend against German dominance, the refugees, as well as the civilian population of Vis, had to find a new temporary home. The first destination was southern Italy, already under Allied control. However, there were no facilities to house the tens of thousands of refugees, and the frontline was too close. Thus, the British proposed evacuation to Egypt, where military camps were available.

Altogether just over 40,000 Dalmatians fled for Italy and most of them were later transferred to Egypt $(39,647)$, while several thousand remained in Italy. These refugees amount to just below 10 percent of the entire population of Dalmatia $(466,000)$, and considerably more in the case of the islands and the central Dalmatian coast. ${ }^{15}$

At first, the camps in the Middle East were run by the British Middle East Relief and Refugee Administration (MERRA). On May 1, 1944, the UNRRA took over. In effect, the British Army guarded the camps, while welfare and food supplies were administered by Americans working for UNRRA. In addition, humanitarian workers, British and American for the most part, worked with the hospitals and schools. Amidst the UNRRA, the British Army, and US relief, the Partisan-led COZ had to carve out their role in the camps, which initially led to tensions with the British. Once in the camps, the COZ established defacto self-government of the refugees. COZ members had traveled with the refugees, were themselves from the same towns and the villages as they were and thus had an authority hard for the allies to ignore. In a November 1944 report, secretary Mate Barbić notes how this work of the COZ constituted a crucial experiment of state building: "The organization structure that will lift the $\mathrm{COZ}$ on a higher level and enable it to fulfill its task-enables it to increasingly

15. The largest share came from the coastal towns of Makarska $(5,841)$ and Vodice $(4,000)$, and the islands Korčula $(4,478)$, Brač and Šolta $(4,324)$, Vis $(3,784)$ and Hvar (2,989), HR-DAST-23-523; “Oblast Dalmacija u brojkama,” Naš List, November 28, 1944; Neven Bogdanić, "El Shatt naš nezaboravljeni," Crkva u svijetu 30, no. 1 (March 1995): 53-59. Data is based on the last census in the Kingdom of Yugoslavia in 1931 and the data of the refugees in El Shatt. 29.2\% of Hvar's total population fled; from Korčula, 21.8\%; Brać and Šolta, 24.9\%; Makarska, 21.8\%. From other locations of Dalmatia, the share was lower (for example, Split 2.84\%, Knin 3.4\%). 
approximate a new form of state power. ...Comrades are afraid of mistakes and taking responsibility, but this is not correct. We have never had people's democratic government and thus we cannot have experience."16

The main camp, El Shatt, was to become a "city with streets, house numbers, schools, hospitals, clinics, post offices, theaters, choirs, football teams, sports clubs, a cemetery, and churches." ${ }^{17}$ It grew steadily in the first months to include a total of five sub-camps, often several kilometers of desert apart and each constituting a little town of its own. At its peak in January 1945, some 24,771 refugees lived in El Shatt. This made it the second largest Dalmatian city after Split, and just slightly smaller than the city of Suez, which was just some ten kilometers away on the other side of the Suez Canal. ${ }^{18}$ Others found shelter in Tolumbat, twenty kilometers east of Alexandria, and Khatatba in the Nile Delta. El Arish, on the Mediterranean coast, hosted those Yugoslavs who rejected Partisan dominance, as well as other "misfits." This article will focus on El Shatt, unless noted in the text, as it became home to the majority of Yugoslav refugees, and with its five sub-camps became the center of refugee life in Egypt. ${ }^{19}$

The arrival in El Shatt was often a shock for the refugees, as Rusko Matulić recalls in his memoirs: "When the freight car doors opened in the morning we came face to face with the torrid desert reality. . .we were assigned to a tent with a wet concrete slab, went to fetch straw mattresses. .." Camp life was harsh, with high temperatures during the day and freezing desert nights. Neven Bogdanić recalls, how despite becoming "quickly used to the new environment, to the cold nights and the unbearable heat. . .in the desert in the middle of nowhere...[we] were caught by the nostalgia for the Adriatic Sea, the peace and quiet of its bay, the scent of sage, lavender, rosemary, pines and the gentle Dalmatian landscape." ${ }^{20}$ The desert wind the refugees called Gibli covered everything in sand, leaving a lasting impression on the refugees. ${ }^{21}$ From rural coastal and island communities shaped by agriculture and the sea, the Dalmatians found themselves in the desert without vegetation in an improvised urban setting few had earlier experienced..$^{22}$

16. HR-DAST-23-442, Izvještaj, Mate Barbić, November 27, 1944.

17. Nataša Mataušić, "El Shatt. Zbjeg iz Hrvatske u pustinji Sinaja, Egipat (19441946)," in Nataša Mataušić, 2007).

18. According to the 1948 census, Zadar had 13,954 inhabitants, Split 48,248, Šibenik, 15, 93, 353.

19. Tolumbat initially hosted refugees that came into conflict with the COZ, but were later transferred to El Arish. Tolumbat was mostly used for convalescing refugees, in particular children, as the Mediterranean climate was milder. It hosted around 20002300 refugees in late 1944. Khatatba accommodated up to around 6,300 refugees, but was closed in November 1944, and most refugees were transferred to El Shatt. UNA, S-10210028-01, UNRRA Historian. George Woodbridge was the official UNRRA historian and published the official history of the UNRRA in 1950 with Columbia University Press.

20. Bogdanić, "El Shatt naš nezaboravljeni," 55.

21. All refugee memoirs note the shock of arrival and the harsh climate, in particular, the wind. See also Bratanić, Hrvatski zbjegovi u Egipat 1943-1946, 203.

22. Rusko Matulić, Feb 1944 El Shatt Egypt Nov 1948 (New York, 2014), 11. 


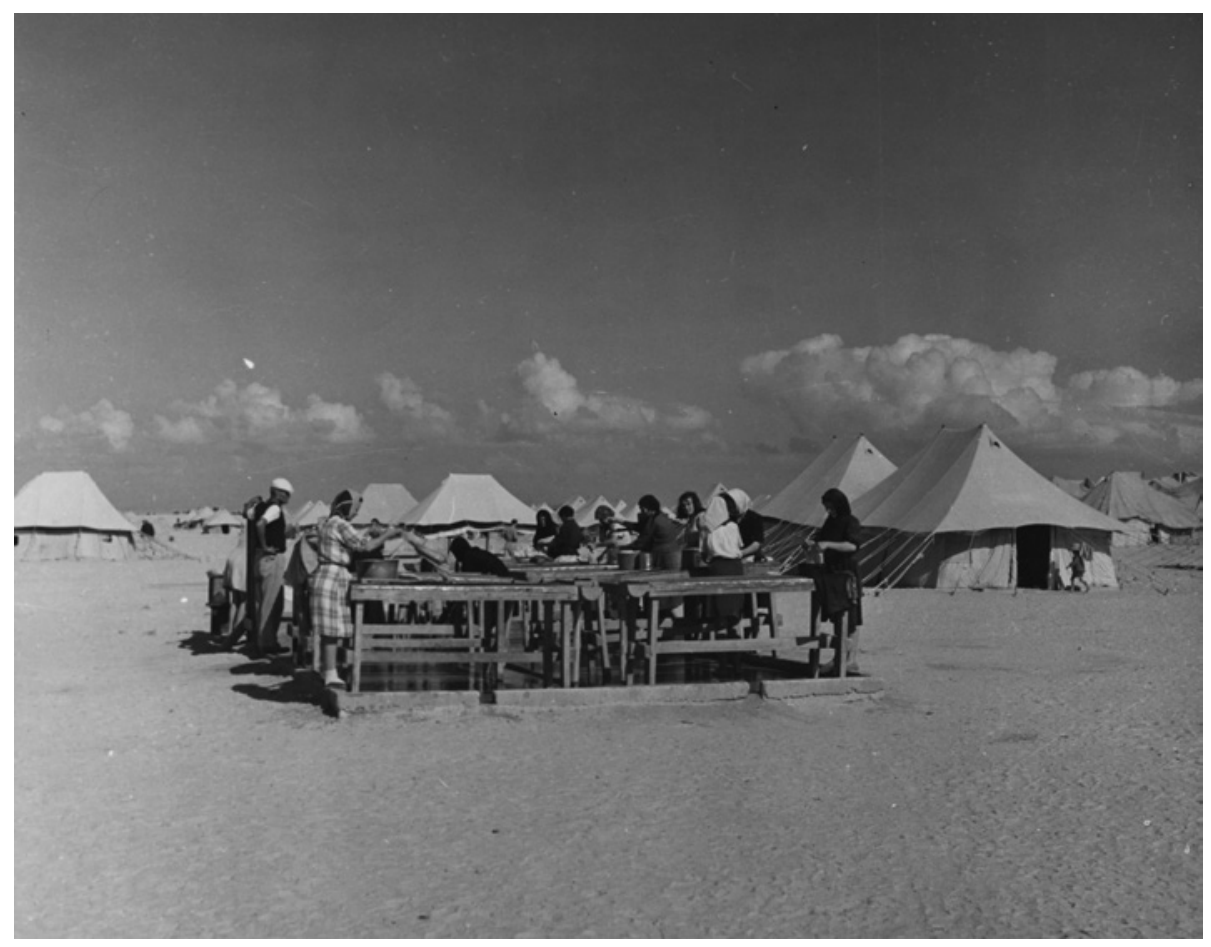

Figure 1. Washing tables in El Shatt (Credit: UNRRA, UN Archives, S-0800-0008-0010).

Upon arrival, refugees were grouped by their villages of origin and assigned to tents that kept villages largely together. Families shared tents, but often also had to share them with strangers or at least non-family members. ${ }^{23}$ A. Tegla Davies, who worked for the Friends Ambulance Unit, described the modest life in the tents: "Each tent has. . .items of home-made furniture improvised out of wooden boxes and pieces of timber. .. For the most part they are kept spotlessly clean, although the same care is not always extended to anything outside their living quarters."24 (Figure 1)

The defining feature of camp life was the extensive organization that permeated all social life. While a sense of idleness often marked other camps, El Shatt was busy. Cultural life began as soon as the refugees arrived. The refugees include some prominent artists who were evacuated together with farmers and fishermen. ${ }^{25}$ Within weeks of their arrival in March 1944, schools were already beginning to operate, newspapers were published, and

23. UNA, S-0520-0298, Information Requested by Refugee Camp Unit, Bureau of Areas, El Shat Camp, S.K. Jacobs, Field Organizers UNRRA, Cairo, May 25, 1944.

24. Arfor Tegla Davies, Friends Ambulance Unit. The Story of the F. A. U. in the Second World War, 1939-1946 (London, 1947).

25. The COZ was aware of the artists that arrived in El Shat and kept a list of writers, architects, and artists that left Yugoslavia for Italy and Egypt. These include the composer and conductor Josip Hatze, who would be a key figure in building up cultural life in the 
theater and choir groups were set up. In addition to singing Yugoslav songs, the choir immediately catered to the circumstances and learned to perform Yankee Doodle and Pack up your Troubles next to communist and traditional Dalmatian songs such as Partizanka and Marijana, giving concerts to American and British soldiers. ${ }^{26}$ Soon afterwards, the repertoire included the national anthems of the allies and an ever increasing number of British, American, and Russian songs. ${ }^{27}$

The camp administration also built up libraries, but books were scarce, and few were available in Croatian/Serbian, increasing the importance of the various publications produced in the camp. ${ }^{28}$ Pupils went to school while adults worked and learned everything from shoemaking to sculpting. In other camps, refugees were paid for their labor by the British, who charged the governments in exile for repayment after the war. The COZ rejected this, however, and only allowed for pocket money to be paid out on the grounds that the Partisans fighting back home also received no pay. The only payment for labor was thus extra bread and cigarettes, the latter a valuable resource. Besides, refugees also received substantial financial support through remittances from relatives overseas, particularly in the United States. ${ }^{29}$

In the eyes of the $\mathrm{COZ}$, working was a central aspect of building the new society and demonstrating the motivation of the refugees. As Henry G. Russel notes in his report, there were more mundane motivations: boredom, interest in the job, being part of a group, or getting away from the women and children. "It gives the men a chance to be with their pals, to be away from the 'old woman,' to talk about politics, and women, and the weather, and they may not work very hard at it, but at least it's 'man's work'; and it gives them a certain amount of self-respect." 30 Of course, women worked no less than the men in the camp, as aid worker Viola G. Pfrommer noted in a letter in November 1944: "One woman does the work of three men and that willingly, even if most were not formally employed." 31

The educational system included kindergartens and daycare, primary and secondary schools, and adult education, including learning reading and writing for a largely illiterate community. ${ }^{32}$ The schools were basic, but the $\mathrm{COZ}$ experimented with some innovations, such as weekly parent-teacher

camp. HR-DAST-23-528, Spisak umjetnika i književnika, koji su otputovali u Bari u mjesec januar 1944. g.

26. HR-DAST-23-466, Izvještaj, Prosvjetnog i propagandnog odjela, March 1944.

27. HR-DAST-23-466, Kulturni-informativni odjel, 10.6.1944, Izvještaj, May 1944.

28. HR-DAST-23-466, Kulturni-informativni odjel COZ, June 1944.

29. UNA, S-1021-0028-01, UNRRA Historian.

30. UNA, S-0520-0298, To James Vail, Nov. 11, 1944 Monthly Report for October 1944.

31. UNA, S-0520-0298, Viola G. Pfrommer, to Margaret E. Jones, Feb. 11, 1944, American Friends Service Committee, Monthly Report for October 1944. In two typical daily rosters for two camps at El Shatt, more than three times more men were employed than women, with women being primarily working in hygiene as nurses, cooks, and teachers. UNA, S-0520-0298, Information Requested by Refugee Camp Unit, Bureau of Areas, El Shat; Camp, S.K. Jacobs, Field Organizers, UNRRA, Cairo, May 25, 1944.

32. In June 1944, nearly 5,000 primary school children were educated according to the new curriculum of the ZAVNOH, while around 500 children attended secondary school, HR-DAST-23-466, Izvještaj, Prosvjetni odela, COZ, for 6-1944, June 30, 1944. 


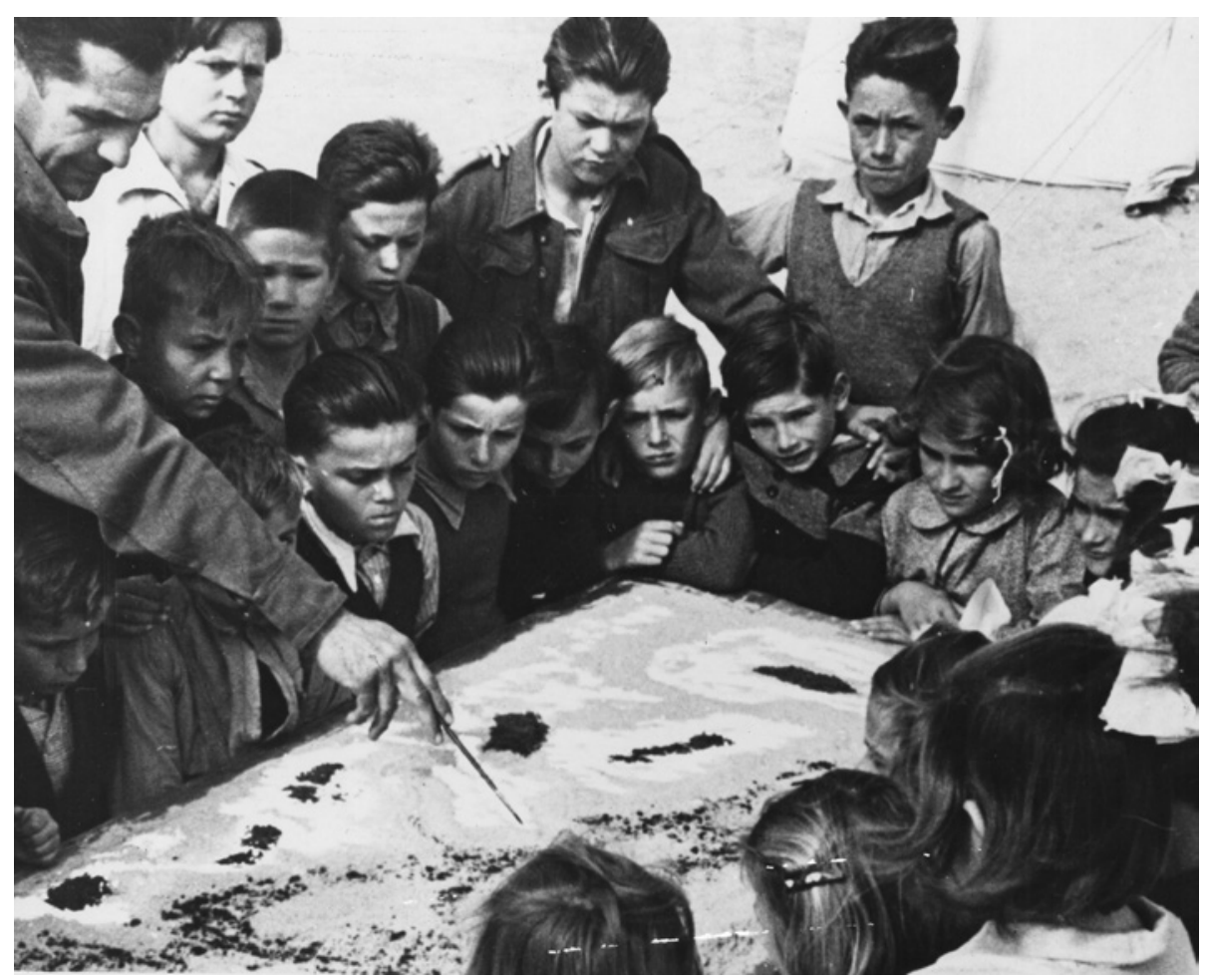

Figure 2. Teaching in school, with relief map of Dalmatia made of sand in class in Tolumbat (Credit: UNRRA, UN Archives, S-0800-0008-0008).

meetings, described by UNRRA as a "very progressive educational technique. . .not used in Yugoslavia, but. . .developed out of a felt need at El Shatt." 33 Reflecting efforts to maintain a good relationship with the Catholic and Orthodox Church, the education included weekly religious instruction. ${ }^{34}$ (Figure 2).

One important aspect of camp life was information about the rest of the world, the war, and the post-war period in Yugoslavia. Information was sparse, as the reception of radio stations, including Radio London, not to mention Radio Free Yugoslavia, was close to impossible and few outside newspapers from Yugoslavia reached the camp. ${ }^{35}$

Considering the distance from Dalmatia and the obstacles to communication, the $\mathrm{COZ}$ had to build up its own media outlets, drawing on reports it received from the Allies and the Yugoslav liaison office in Cairo, as well as newspapers from Dalmatia. These included the daily Naš list, which was published throughout the period. ${ }^{36}$ Besides, the $\mathrm{COZ}$ printed a range of

33. UNA, S-1309-000-0048, Information about camps for children, Edward C. Harold for Mss. Gifford, 22.6.1945.

34. Bratanić, Hrvatski zbjegovi u Egipat 1943-1946, 160.

35. HR-DAST-23-466, Izvještaj, propagandnog odjela, April 1944.

36. It initially consisted of around six pages and was printed in 450 to 660 copies. Over time, the production quality and the print run increased. Ibid. 


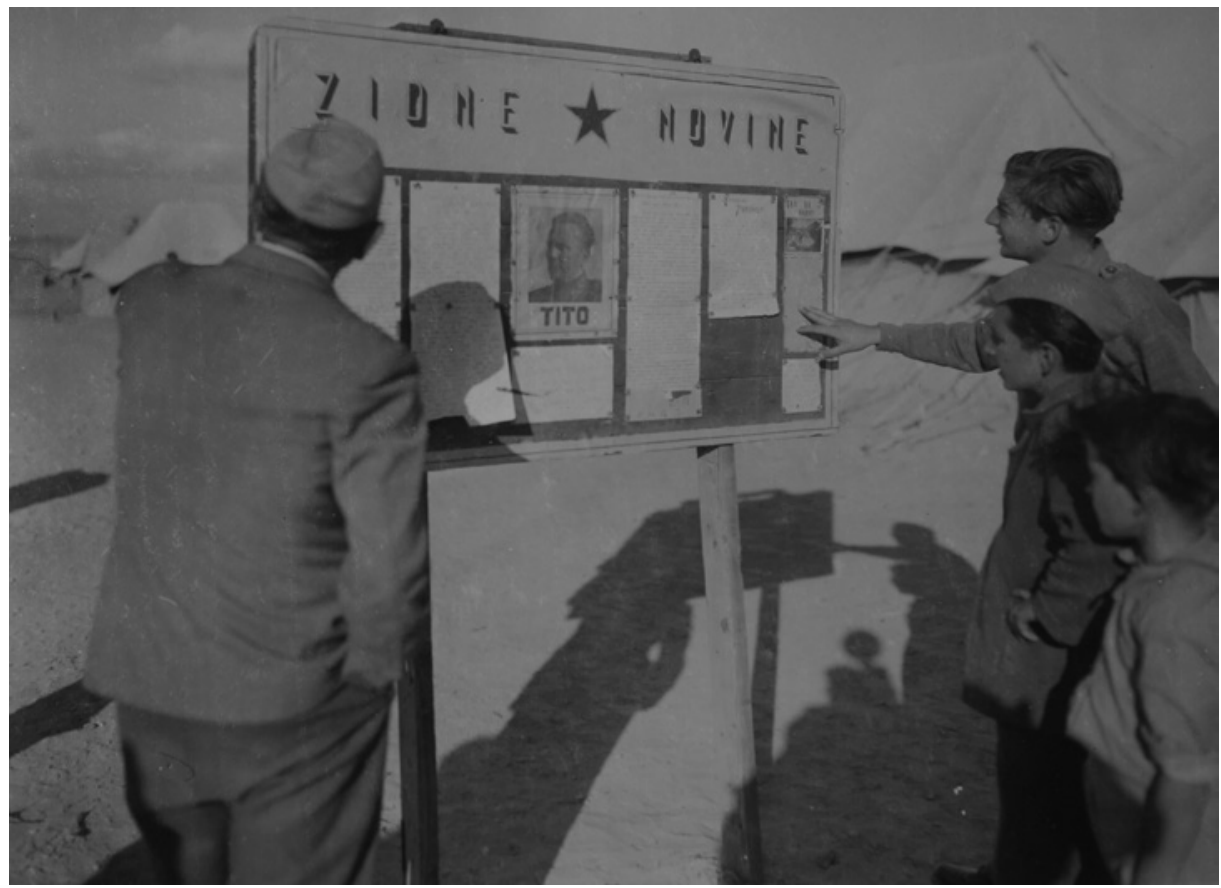

Figure 3. Refugees reading camp newspaper in El Shatt, April 1946 (Credit: UNRRA, UN Archives S-0800-0008-0010).

other periodicals, as well as other publications, including partisan songs and textbooks for schools. ${ }^{37}$ Considering that the COZ held a monopoly over printed information, it could control the news flow. Naš list and all the other publications supported the Partisan movement and followed the line of the leadership. ${ }^{38}$ (Figure 3).

In addition to media, there was an impressive range of events organized throughout the camps. Cultural evenings included lectures, readings and recitals, singing of partisan and patriotic songs, theater performances, and traditional kolo dances. There were typically three to four cultural evenings in all the camps' districts each month, some attended by up to 1,000 people. ${ }^{39}$

An important part of entertainment was soccer and sports in general: there were some eight sports clubs, with 1,241 members, in June $1944 .{ }^{40}$ The

37. The smaller camps had their publications and specialized periodicals targeting the youth (Omladinski riječ, Naš pionir) and women (Žena u zbjegu). Wall newspapers, under the authority of the different sub-camp organizations, provided for additional information.

38. HR-DAST-23-445, Kulturno-informativni odjel COZ; Izvještaj, August 1944.

39. Ibid.

40. Soccer clubs named Partizan, Jadran, Borac, Udarnik, Dalmatinac, Slaven, Omladinac and Sloboda-names that reflect the Partisan movement-played regular matches. HR-DAST-23-445, Izvještaj, Prosvjetni odela, COZ, for 6-1944, June 30, 1944. 
most legendary game was a visit by the Split soccer club Hajduk on May 11, 1945, less than a week after the end of the war. In front of 8,000 spectators, Hajduk played against the camp club Jedinstvo. Even though Hajduk won 4-0, the internal the COZ report noted large celebrations and a cheerful evening. ${ }^{41}$

The British and American aid workers and UNRRA staff repeatedly noted their admiration for the resilience of the refugees in the camps. For example, William B. Edgerton, writing to his wife from the camp via the American Friends Services Committee, noted that "I must not give the impression that these people have managed to create a little paradise here on the desert with their resourcefulness. . .their extreme lack of everything. . .only makes what they do accomplish more impressive, standing as it does against such a background." "42 An UNRRA report from 1944 came to a similar conclusion, noting the "high pitch of enthusiasm that the refugees maintain." While far removed from Yugoslavia, the connection remained strong, as they "are a piece of Yugoslavia transplanted to the Egyptian desert until such a time as they can go back to Yugoslavia." 43

Beyond the emotional connection to Yugoslavia, reinforced by the desolate conditions in the desert and the temporary nature of their stay, the institutional structures of camp life ensured the connection to Yugoslavia-the Yugoslavia slowly established by the Partisans.

\section{Building a Yugoslav State}

The well-organized camp life was the result of meticulous planning. The COZ worked like a mini-government in the camps, including five departments (Economic, Education, Culture and Information, Technical Matters, and Health), each directed by two officials as well as a president and secretary, and supported by an administration. ${ }^{4}$

Reflecting on the camp committee in Tolumbat, UNRRA official G. Chesters noted that "in practice the committee in its present stage holds the position of a ministry of domestic affairs, and its growth and effort tend towards turning itself into a completely responsible government." 45 This structure was replicated in all the camps and districts, resulting in a total of 195 committee members in all camps. ${ }^{46}$

41. HR-DAST-23-445, Logorski odbor, 5, Kulturno-informativni odjel, El Shatt, May 1945. The Hajduk soccer team joined the partisans on Vis and played in El Shatt as part of a Mediterranean tour, playing against allied clubs from Malta to Egypt.

42. UNA, S-1303-0000-1654, El Shatt Camp 270, December 1, 1944.

43. UNA, S-0520-0298, Combined Economic Warfare Agencies, Yugoslav Refugee Camps in Egypt, May 21, 1944.

44. HR-DAST-23-445, COZ August 16, 1944, President-Ivo Markić; Secretary-Mate Barbić; Administration-Dušan Arneri; Economic-Mate Plosnić and Niko Oklopdijia; Education-Zoran Palčok and Don Andro Štambuk; Culture and Information-Ivan Jurlina and Marija Lujak; Technical-Zvonko Bešker and Ivo Franetović; Health-Milivoj Visković and Milan Bjelić.

45. UNA, S-0520-0298, UNRRA Refugee Camp-Tolumbat, G. Chesters, February 13, 1945.

46. HR-DAST-23-442, Izvještaj, Mate Barbić, November 27, 1944. 


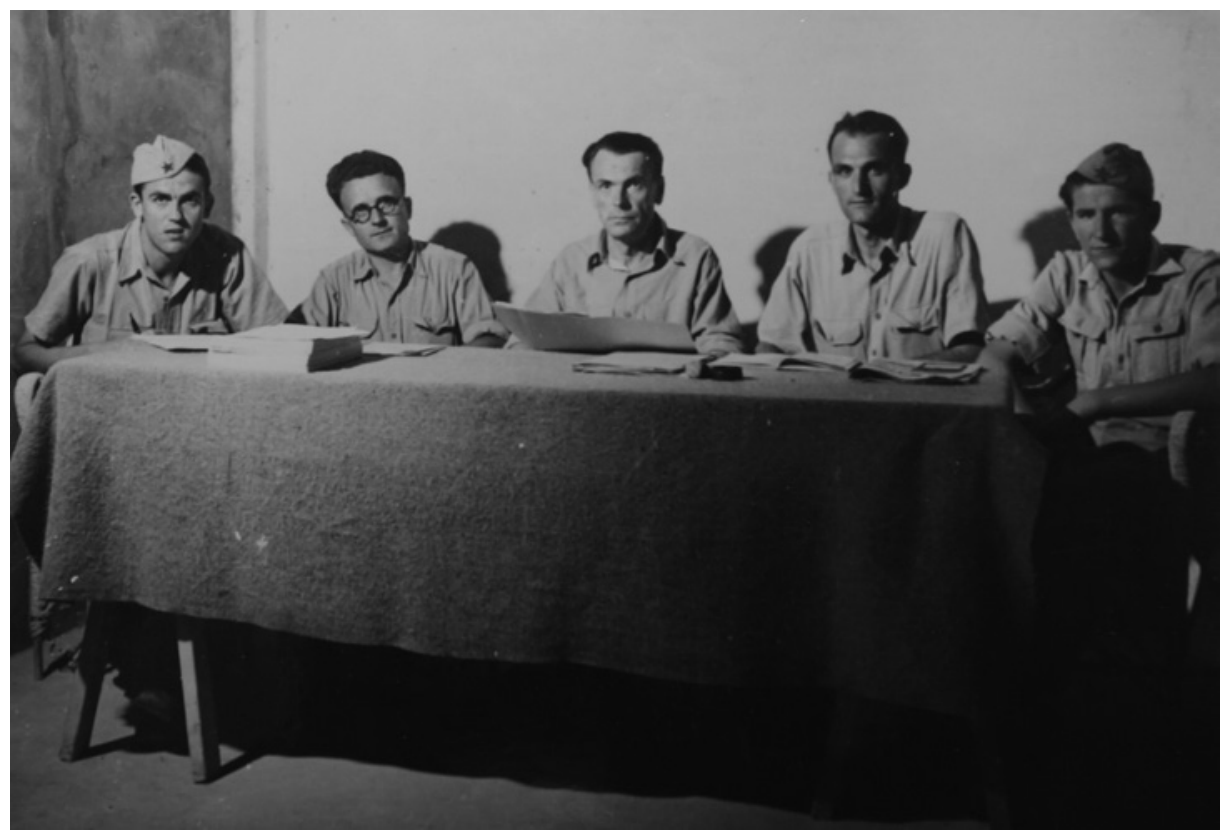

Figure 4. COZ leadership, including Ivan Jurlina, Milovoj Visković, Ivo Markić, Mate Barbić, Mate Plosnić (left to right) (Credit: UNRRA, UN Archives, S-0800-0008-0010).

The KPJ (Communist Party of Yugoslavia) controlled the camp administration through the COZ. In all of the Egyptian camps, however, there were only 371 party members and 132 candidates, of which only fifty-six were accepted during the period..$^{47}$ The party was represented in the COZ; but it included others as well, such as Andro Štambuk. As a priest, he was responsible for education in the camps for most of the period, making him one of the most influential non-communist officials. His relations with the Partisans were overall sound, and as a priest, he helped dispel concerns among the Allies over religious repression by the Partisans..$^{48}$ In addition to Štambuk, who was the most senior clergy and maintained contact with the Catholic church in Yugoslavia, there were a further five priests, which is a relatively small number. Asked why he joined the Partisans, one replied: "Because I am a priest and I think like the people." ${ }^{\circ 9}$ (Figure 4).

All of the committees had members representing other political orientations. For example, the committee of camp 1 had four sections (administrative,

47. During the same period, there were fourteen disciplinary punishments of party members and five were dismissed from the party.

48. Štambuk did not join the party and remained loyal to the Catholic Church upon his return, which led to his isolation in Communist Yugoslavia. Bratanić, Hrvatski zbjegovi u Egipat 1943-1946, 163.

49. UNA, S-0520-0298, Combined Economic Warfare Agencies, Yugoslav Refugee Camps in Egypt, May 21, 1944. 
economic, educational, and technical) with ten members, including five Partisan sympathizers, four supporters of the Croatian Peasant Party, and one Yugoslav nationalist. Similarly, the $\mathrm{COZ}$ detailed the different party sympathies in the camp committees of the camps and their sub-districts, highlighting that the leadership was quite pluralist..$^{50}$ Non-communists were less central to the running of the camps and would become more marginal upon their return to Yugoslavia. Communist dominance was possible through mass organizations, such as the League of Communist Youth of Yugoslavia (Savez komunističke omladine Jugoslavije, SKOJ) and AFŽ.

While the idea of elections to the camp committees was raised by both the Allies and some critics of the $\mathrm{COZ}$, the leadership rejected this. It argued that considering the large number of women and children, whose husbands were fighting in the homeland, it would be "unfair to raise the question of elections in exile," also arguing that the population was "incomplete" and in exile, making elections less necessary or possible. ${ }^{51}$ These reasons are only partly convincing, especially considering the overall reluctance of the Partisans to hold free elections. In the end, elections were held in December 1944 for the United Peoples' Liberation Front (Jedinstvena narodnooslobodilačka fronta, JNOF). With high turnout, the elections confirmed the dominance of candidates sympathetic to the National Liberation Movement. In the commission for the front, parties other than the Communist Party were also represented. In fact, ten were members of the Croatian Peasant Party, one each from the Radical Party, the Yugoslav National Party, and the Democrat Party, two Communist Party members and two non-party members. ${ }^{52}$

Beyond the committees, schools, and other services, the COZ also organized courts and unarmed Partisan guards, who acted as an internal police force and also protected the camp together with the British Army guards. ${ }^{53}$ Each camp had a designated official responsible for the partisan guard. There was a commander for each camp, a deputy commander, a political commissar, and his deputy. Each camp had between nineteen (Tolumbat) and 115 guards (El Shatt camp 3) on duty day and night. ${ }^{54}$ In June 1944, for example, Partisan guards noted sixty-three violations, both disciplinary and criminal. It also monitored contacts with the outside world, noting contacts with the government in exile or black-market activities, as will be discussed next. The courts also took on criminal and civil cases: in June 1944, some 177 were pending, with 148 having been resolved. ${ }^{55}$ UNRRA accepted the authority of the courts. UNRRA and the British were overall grateful for this internal policing and court system, as the "presence of such a refugee administration set-up removes from the shoulders of the camp staff a thousand and one petty problems that crop up daily." 56

50. HR-DAST-23-507, Izvještaj, COZ iz Jugoslavije March 1-31, 1944.

51. HR-DAST-23-442, Izvještaj, Mate Barbić, November 27, 1944.

52. Bratanić, Hrvatski zbjegovi u Egipat 1943-1946, 122.

53. HR-DAST-23-507, Izvještaj, Upravnog administrativni odjelo, June 1944.

54. HR-DAST-23-445 COZ, El Shatt, 2901-45, Izvještaj, May 19, 1945.

55. HR-DAST-23-507, Izvještaj, Upravnog administrativni odjelo, June 1944.

56. UNA, S-1309-000-0048, S.K. Jacobs, to Laird Archer, Report on El Shatt Camp, May 25, 1944. 
Throughout the camps, the $\mathrm{COZ}$ and the Partisans were able to prove to the Allies their ability to administer the camps effectively, as the UNRRA acknowledged: "if the Yugoslavs have the tools and equipment to keep them busy both at work and at play the camp will function as smoothly and as quietly as a new electric refrigerator." ${ }^{57}$ UNRRA officials took this as evidence of the Partisans' ability to manage reconstruction in Yugoslavia, as " $[t]$ hese people have demonstrated that they are industrious and trustworthy and when the war ends the Yugoslavians should be able to meet their own problems with a minimum of administrative effort and supervision on our part." 58 In effect, such assessments affirmed the goal of the COZ to project a sense of autonomous state building in the camps.

State-building in El Shatt was thus first and foremost reflected in the elaborate control and organization of the camp population. In addition, statebuilding also shaped self-perception. Thus in 1945, the COZ noted the importance of the experience of El Shatt as part of the larger post-war Yugoslav state-building:

"And as it is honorable. . .to be in Tito's army, it is also honorable to be part of the refugee community ( $(\mathrm{bijeg})$, which is itself a result of the struggle. But it is only honorable if through work, organization, discipline, and order we demonstrate our worthiness to those heroes who continue the fight for the liberation of our homeland. . ."59

The importance of state-building was thus clearly set in relationship to the armed struggle back home. The goal of the refugees was to build institutions and work and to prove their worthiness in the eyes of the Partisan fighters in Yugoslavia, a recurring theme in the public and internal communication of the COZ. In addition to establishing legitimacy in exile, state-building also served to "tackle a new challenge, which will be the continuation of this work, and that is help in organizing life and work in liberated Yugoslavia, the renewal of the country." ${ }^{60}$ Finally, as shall be explored next, it also served to build the legitimacy of the Partisan movement in the eyes of its western allies.

\section{Relations with the Allies}

During the first weeks of the camps, the British did not recognize the COZ, but only individual camp committees, and wanted to work through these directly. The COZ was quickly able to assert its control, however, and eventually both the British Army and UNRRA looked favorably on the COZ. ${ }^{61}$ UNRRA, once

57. UNA, S-0520-0298, El Shatt Camp S.K. Jacobs, Field Organizers UNRRA, Cairo, May 25, 1944.

58. UNA, S-1309-000-0048, S.K. Jacobs, to Laird Archer, Report on El Shatt Camp, May 25, 1944. Different UNRRA and British officials, as well as British and American aid workers repeatedly note with admiration the functioning of the COZ-led administration, see UNA, S-0520-0298, Combined Economic Warfare Agencies, Yugoslav Refugee Camps in Egypt, May 21, 1944; Davies, Friends Ambulance Unit): Michael Barratt Brown, From Tito to Milosevic: Yugoslavia, the Lost Country, (London, 2005).

59. HR-DAST-23-445, Reorganizacija u svim odborima, no date, circa 1945.

60. HR-DAST-23-445, Izvještaj, Mate Barbić, November 27, 1944.

61. HR-DAST-23-508, Izvještaj, COZ iz Jugoslavije, March 1-31, 1944. 
it took over, was particularly impressed by the Partisans. As S.K. Jacobs of UNRRA noted: "Yugoslavia has been the only occupied country to field an above ground, organized anti-fascist team, and the spirit that made an army out of peasants and fishermen is evident even to a stranger at El Shatt."62 Similarly, Henry Scattergood of the American Friends Service Committee saw the strong ideological orientation of the refugees positively, noting that "[t]hey are very politically-minded, for the most part strongly Partisan (proTito) in their loyalties. . .unlike many European refugees they in all likelihood have something to go back to."63

Some observers took a more critical view of the efficiency and ideological control of the COZ. As Samuel Yoder, a doctor working for the Mennonite Central Committee, noted: "[i]t gave one an eerie feeling to see this totalitarian system gradually taking over and regimenting the lives of the people. They were good, sound, human stuff; simple, genuine, hard-working peasants. . .it was marvelous the way that they kept up their morale in the wasteland of heat and sand." 64

The three principal sources of tension between the British and the $\mathrm{COZ}$ were the role of the $\mathrm{COZ}$ and the degree to which it would be able to run the camp autonomously; the question of how to deal with dissent and those who sought to leave the camp; and finally, the slow pace of repatriations, which seriously undermined morale and thus also the reputation of the COZ. Initially, the British and the Partisans encountered each other with a certain degree of suspicion. Thus, Tito's close associate Vladimir Dedijer wrote about the camps and how a British officer promised to "break this arrogant communist spirit," a claim that might be plausible for some officers, but certainly not the entire British Army managing the camps. It is certain that the English officers, who expected to find a group of helpless refugees, were greatly surprised at how quickly they set up their infrastructure in the camps. ${ }^{65}$ UNRRA would have preferred a more democratic system in El Shatt, "as an international organization which could not be suspected of a desire to gain control over Yugoslavia's internal affairs, it [UNRRA] might, had it organized the refugee camps from the start, have been able to insist on greater personal freedom for all the camp inmates." However, the system was firmly in place and could not easily be changed. ${ }^{66}$

In the first months, tensions were greatest between El Shatt Camp Commander John Langman and the COZ. An attempt by some Yugoslavs to leave the camp was the catalyst for the crisis. For the British, the discovery that Partisans had forcibly evacuated people to the camp violated the initial agreement, according to which only those voluntarily evacuated should be in the camps. On the other hand, the COZ considered Langman's intervention as interference. The conflict was resolved following a meeting with the Yugoslav

62. UNA, S-0520-0298, Information Requested by Refugee Camp Unit, Bureau of Areas, El Shatt Camp S.K. Jacobs, Field Organizers UNRRA, Cairo, May 25, 1944.

63. UNA, S-0520-0298, Henry Scattergood, Casablanca, April 21, 1944.

64. Samuel Alvin Yoder, Middle-East Sojourn (Scottdale, Pen., 1951), 49.

65. John Corsellis, "Yugoslav Refugees in Camps in Egypt and Austria 1944-47," North Dakota Quarterly 61, no. 1 (Winter 1993): 40-54.

66. UNA, S-1021-0028-01, UNRRA Historian. 
liaison office, UNRRA, and British officials in Cairo on March 4, $1944 .{ }^{67}$ The agreement between the British government and the Partisans meant that the latter retained autonomy over the internal affairs of the camps and the British ensured that the camps would not be infiltrated by supporters of the Royalists, associated with the Yugoslav government in exile located in part in Cairo.

The de-escalation was also linked to the appointment of Mate Jakšić as a liaison between the Partisans, the COZ, the British, and UNRRA in Cairo, who took a pragmatic line and later noted in an interview that "many. . .wanted to implement a rigorous and inflexible policy and were not aware that they had to cooperate with the Allies, since they were no longer the Partisan Army." 68 Relations improved, but tensions with anti-communist British officers persisted. Royalist and other opponents sought to be employed by the British to maintain contact with the outside world. ${ }^{69}$

Once the British Army replaced Langman in the summer of 1944 and a division of labor emerged between UNRRA, the British Army and the COZ, relations grew cordial. In addition to the regular concerts and performances, the $\mathrm{COZ}$ also organized an exhibition about the camp for the Allies in June 1944, with the aim of showing how the refugees "in new and challenging circumstances, without necessary materials, get to work."70 "To exhibit what we know and can do, we want to show how we have dealt with and how we live in exile."71

For the $\mathrm{COZ}$ and the Partisans, establishing good relations was important, also in terms of proving their worthiness as allies, as COZ Secretary Mate Barbić noted in a report in April 1944:

"Our relationship towards the Allies, the English authorities in this case, in general is correct and normal, and the autonomy of our committees is fully recognized by the English, who consider them able to resolve all problems. Today our authority can no longer be avoided, not even in the smallest and unimportant matters. There is no doubt that the English and Americans, through the exiled, and through our ability in exile, value and appreciate the ability of the people of Yugoslavia to build a new state after liberation."72

Relations further improved as allied support shifted decisively to the Partisans, whereas the credibility of the Yugoslav government-in-exile declined and the Četnik movement increasingly collaborated with the Axis forces. Weekly meetings between the camp committees and the camp commander took place to deal with all sorts of complaints, such as the quality of the bread. ${ }^{73}$ At the same time, the Partisans also kept a close eye on the Allied officers at the

67. Ibid.

68. Kornelija Ajlec, "Jugoslovanski begunci v Egiptu in njihova politična opredeljenost 1943-1946,” Zgodovinski časopis 67, no. 3-4 (2013), 444.

69. Bratanić, Hrvatski zbjegovi u Egipat 1943-1946.

70. HR-DAST-23-466, Kulturni-informativni odjel, June 10, 1944; Izvještaj, May 1944. 1944.

71. HR-DAST-23-466, Izvještaj o prvoj općoj izložbi zbjega i jugoslavije, June 25-28,

72. HR-DAST-23-507, Mate Barbić, Izvještaj, COZ, April 15, 1944.

73. UNA, S-1309-000-0048, S.K. Jacobs, to Laird Archer, Report on El Shatt Camp, May 25, 1944. 
camp to ascertain their support or hostility, noting the Allies were resentful when their assistance was not acknowledged. ${ }^{74}$

\section{Repartition and the Long Return Home}

When the war ended, and the refugees began to return, there was great excitement in the air: "Our peoples' government, music, as well as the entire people of the refugee community accompanied the first groups, who impatiently awaited the hour of their journey. . .we will build with song and music a new happy free democratic federal Yugoslavia..."75 There were some tensions among the refugees about who would return when, but the repatriation ran smoothly at first. ${ }^{76}$ This excitement quickly gave way to frustration, however: the repatriation came to a standstill after the first ten transports between April 11 and July 18 brought 18,985 back, more than half of all refugees. ${ }^{77}$ The British Army justified the delay due to a shortage of ships in the Mediterranean, as ships were needed in the Asian theater of the war. ${ }^{78}$ As time went by, however, the Yugoslav authorities, as well as the COZ, grew impatient. ${ }^{79}$ Not only did they want their citizens' return, but the inhabitants of the camps grew understandably restless. As the COZ noted in mid-1945, "the people [in the camps] always understood and correctly interpreted everything that was explained to them, but there were individuals who wanted to convince the people that the peoples' government as well as the commission [for repatriation] does not take sufficient account of the people and that delays are caused by this." 80

The slow return was embarrassing for authorities, "especially in view of the fact that the same military authorities who have declared that there is no shipping available to transport Yugoslav refugees have provided shipping for the return of Greek refugees." ${ }^{11}$ This was particularly surprising, as

74. For example, COZ reports noted that Jolly Stephan, a deputy commander, met with Royalist Yugoslavs in Alexandria. HR-DAST-23-507, Izvještaj, 2, n.d. probably 1944. A British embassy report of February 15, 1945 noted a lecture by Mate Jakšić in Belgrade where he did not mention allied support for refugees in El Shatt. A Foreign Office officer comment to this report "typical.” FO 3751/51184.

75. HR-DAST-23-466, Logorski odbor, 5, Kulturno-informativni odjel, El Shatt, Izvještaj za kroniku, April 30, 1945.

76. HR-DAST-23-466, Izvještaj, Osjek za kroniku logora 5, May 15, 1945.

77. HR-DAST-23-445 Komisja za repatriaciju jugoslovenskog zbjiega 29. srpanj, 1945, izvješta o radu komisije za vrijeme od početka (28.3.1945) do 1.8.1945.

78. This appears to be the case, as minutes and internal correspondence of the British Foreign Office suggest. William Deakin wrote from his post in Belgrade that "the evacuation and care of refugees in Egypt has been one of the instances in which AngloYugoslav cooperation has worked reasonably well, and it seems unfortunate that this successful operation should finish in an atmosphere of recrimination and bitterness" (October 29, 1945), FO 371/51184.

79. UNA, S-1302-0000-8587 / 8589, Telegram from, Herbert H. Lehman to Fred K. Koehler, October 16, 1945.

80. HR-DAST-23-445 Komisja za repatriaciju jugoslovenskog zbjiega 29. srpanj, 1945, izvješta o radu komisije za vrijeme od početka, March 28, 1945 do August 8, 1945.

81. Ibid. Internal correspondence of UNRRA reveals a sense of embarrassment about the delays. As Fred K. Hoehler wrote to UNRRA director Herbert H. Lehman: "the 
the Greek government had requested a delay in the returns, while the new Yugoslav authorities urged for quick repatriation. ${ }^{82}$ Considering the relative proximity of the Greek islands, repatriation of Greek refugees was logistically easier. The returns to Yugoslavia only resumed in October 1945, followed by smaller transports in November. Only in January 1946 did the repatriation pick up again. ${ }^{83}$ The delays contributed to rising tensions between the new Communist Yugoslav government and its earlier western Allies, while simultaneously giving rise to a last wave of dissent among some refugees against the leadership.

Overall, the COZ was able to establish itself unchallenged in the camps and make itself an indispensable partner for the Allies. While some had misgivings about their ideological control, the Partisans' anti-fascist orientation, and moreover their efficiency, which aided the British Army and UNRRA in administering the camp, trumped other concerns.

\section{Opposition}

The most sensitive topic, both for internal and external state-building, was dissent. The refugees were ostensibly evacuated for their fear of reprisals by Axis forces and were assumed to be supportive of the Partisan cause. Besides, the Committee sought to build a new Yugoslav society in the camps, and dissent was not welcome. However, not all refugees shared the enthusiasm for the new Yugoslavia. Throughout the two years in Egypt, hundreds sought to leave the camp, and others were dissatisfied or in outright opposition to the prevailing communist ideology that became more visible and prevalent as time went on.

Unlike in Yugoslavia, where opponents were often executed, this option was not available to the Partisans under the watchful eye of the western Allies. For those rejecting the new communist message, there were two options: either exit, leaving the camp, knowing that a return to Yugoslavia was no longer possible, or keep their opposition to themselves or confined to small circles. Even then, however, opposition could not be kept a secret from the Partisans. Through informers, the camp leadership kept a close watch on political opponents and sought to minimize their influence.

While the vast majority had been supportive of the Partisans, some opposition emerged early on in the camp. During the first weeks in the camp, a self-identified Royalist, followed by a priest and another refugee asked to be transferred to another camp; the British camp administrators acknowledged this request. The question of loyalty and opposition to the Committee was the biggest test for relations between the Allies and the Partisans in El Shatt, as

delay in repatriation is causing unfavorable comment in Yugoslavia and the situation is embarrassing to our Mission there. UNA, S-1302-0000-8588, Fred K. Hoehler to Herbert H. Lehman, October 16, 1945.

82. Ibid. "the Greek government has consistently requested that Greek refugees be not returned in great numbers ...., while the Yugoslav government has consistently asked UNRRA to increase the rate of repatriation."

83. HR-DAST-23- 445, Izještaj o radu komisije za vrijeme od 1 augusta 1945 do 1 marta 1946, Komisija za repatrijaciju Jugoslovenskog Zbjega, El Shatt, March 1, 1946. 
noted in the previous section. After the first transfers as the camps were first set up in March 1944, the British sought to allow for the transfer of all those who wanted to leave. While the $\mathrm{COZ}$ agreed, they insisted that only identification as Royalists would be acceptable grounds for transfer and that known Royalists would also be required to leave, thus allowing the Committee to weed out potential opposition. Some eighty refugees signed on and had stones thrown at them, mostly by teenagers. The Committee insisted on interviewing all the "Royalist" refugees individually, which the British commander Langman conceded under the condition that a British officer would be present and their transfer would go ahead. From these interviews, it emerged that the so-called "Royalists" included several disparate groups: some were former Yugoslav soldiers who had been interned in Italy and were not part of the initial group of refugees; others were former civil servants who felt duty bound to the state; and "most were surprised at the idea that Royalists were automatically the enemies of the Partisans and vice versa." ${ }^{84}$ Finally, some claimed to have been evacuated from Dalmatia against their will by the Partisans. Subsequently, all refugees who did not support the Partisan leadership were transferred to Tolumbat and later to El Arish. These were camps for the "difficult" cases among the refugees. Besides Yugoslavs who were deemed "Royalists" or "neutral," there were Greek "troublemakers": ironically mostly communists who had been evacuated against their will from Greek islands and Italians who were settlers on the Dodecanese islands. ${ }^{85}$

During the first months in exile, the COZ noted opposition, which it attributed to Ustaša and Četnik elements, the lack of full Allied support, and the difficult conditions in the camps. ${ }^{86}$ From his perspective, the US ambassador to the Yugoslav and the Greek governments-in-exile, Lincoln MacVeagh, noted after a visit to the refugee camps that "Greeks have politics in their heads but the Yugoslavs have hatred in their hearts." The "hatred" MacVeagh mentions refers to the polarization that had occurred during the previous three years of war in Yugoslavia and the paradox that Četniks in Dalmatia, often collaborating closely with the Italian occupiers, had frequently fought with Partisans, yet in Egypt both were still supported by the Allies. Thus, the matrix of Axis vs. Allies did not fit the Yugoslav pattern. Some Yugoslavs, whom he called "Četnik sympathizers," had been taken to a different camp: "they were pitiful creatures, mostly old women and children, but nevertheless the British authorities assured me that their danger had been real and acute." ${ }^{87}$ In the Tolumbat camp in May 1944, 528 non-Partisan Yugoslavs were housed: a mixture of former soldiers from different parts of Yugoslavia, as well as Dalmatians who did not want to remain under Partisan control. ${ }^{88}$ Their number was less than three percent of the entire Dalmatian refugee population in El Shatt. After the first wave of refugees left, there was still some dissent, as Yoder recalls, but no longer any open opposition:

84. UNA, S-1021-0028-01, Office of the Historian 1941-1953.

85. Ibid.

86. HR-DAST-23-507, Izvještaj, COZ iz Jugoslavije March 1-31, 1944.

87. UNA, S-0520-0298, Lincoln MacVeagh to Secretary of State, March 14, 1944.

88. UNA, S-0520-0298, Population at Camps, May 23, 1944. 
"Sometimes there was complaining, subdued and careful, of course. There was the day of the election, for example. It was done in the open by a show of hands; there was one candidate for each office. Intelligent dissenters seemed to know that it was a farce. There were a few avowed Royalists, but most of them had long since been banished to another camp. Some others styled themselves democrats; they were not popular with the governing committee." 89

The COZ categorized its opponents into five categories: a) long time opponents who had already rejected the national liberation movement in Yugoslavia; b) former officials with "unfulfilled ambitions"; c) former Partisan officials who became estranged in exile; d) undisciplined people, and e) people who were not enemies of the National Liberation Movement but "lack consciousness and do not have the strength to endure."90

Finally, there were different reasons for ending up in the Egyptian camps, unsurprisingly not without relevance for their support for the emerging order. While most had fled the advancing German troops, not all did so voluntarily. Among those who ended up in El Shatt against their will, one can distinguish between two groups: there were those who had been forcibly evacuated from Vis, and those who had been forced to leave from other places because the Partisans considered that they would have been a security threat if they had remained.

Most civilians of Vis were evacuated against their will, as the island was transformed into a military outpost of the Partisans, with British support. While the other refugees knew their towns and villages were under German rule and the risks of returning were great, many islanders from Vis resented being forced from their island and not all were partisan sympathizers. ${ }^{91}$

Another group who unsurprisingly resented the Partisans was comprised of those who had been forcibly taken to El Shatt. These were relatively few and included people accused of being Ustaša supporters, HSS supporters, and Yugoslav nationalists. It was often feared that they would divulge important information to the German occupying forces. However, they appeared to not be sufficiently associated with the enemy to have been executed back in Dalmatia. Many of those forcibly taken claimed that they did not know the reason for their abduction, such as the 64-year old Franka Carković from Brač, who sought to leave for El Arish, noting that:

“I don't know why, I, a peasant woman (seljakinja) who doesn't know to read and write [was abducted]. Italians killed my husband a year ago. I don't want to stay in the camp as everyone from my home has left. I like Tito, the Partisans, and King Petar. For me, all are brothers. I go where my fellow villagers take me. I am not happy because I am not in my home. The Partisans expelled me from my home and I curse them forever in heaven and earth."92

89. Yoder, Middle-East Sojourn.

90. HR-DAST-23-507, 48, Mate Barbić, Izvještaj, COZ, April 15, 1944.

91. Ibid.

92. HR-DAST-23-507, Saslušanja lica koja su napustila naše logore i prešla emigrantskoj vladi u Kairo, Februar 1944. 
Overall, the COZ did not want political opponents from Yugoslavia in the camps. Noting difficulties with a refugee transport from Vis, the Committee note demanded that “. . . it is in general necessary not to send reactionaries here, but hold them in the homeland if this is possible." 93 Nevertheless, the Partisans did send people to El Shatt against their will, and knew of their loyalties. ${ }^{94}$

The political opponents of the Partisans belonged to all shades, and the COZ closely monitored them and attributed to them either an affiliation with their wartime opponents, mostly either Ustaša or Četniks, or associated them with one of the pre-war parties, such as the Croatian Peasant Party (Hrvatska seljačka stranka, HSS) or the Yugoslav Radical Community (Jugoslovenska radikalna zajednica, JRZ). Such labels are inherently problematic. As noted above, people associated with some of the same parties, in particular the HSS and the "Yugoslav nationalists," were also among the accepted members of the camp committee. Furthermore, when exploring the biographies of those who were considered enemies, a more complex picture emerges. The label "Četnik" was used liberally to describe anybody identifying with the government-in-exile or those who expressed their loyalty to King Petar II, or even just for opposing the communists. This is exemplified by the statement of Frano Luger, from Split, who sought to move to El Arish:

"by my understanding, all who are fighting against communists in the peoples' liberation struggle call themselves 'Cetniks.' During the celebration of the $26^{\text {th }}$ anniversary of the [Russian] revolution on the place of honor, there was a communist flag and not the Allied English and American [flag]. Why do we carry the five-pointed star and not a national symbol? This means it is a party struggle." 95

Some called themselves neutral, others Royalists, others nationalists, and Stevo Popović from near Benkovac declared that he was for "all the kings in the world." 96

Their motivations were diverse, but few would have identified with the Četnik movement in Yugoslavia led by Draža Mihailović. As many of those whom the COZ considered Četniks were Catholic Croats from the islands, for whom the Serb nationalist project of the Četniks in Yugoslavia would have been attractive only in exceptional circumstances. Instead, some considered themselves loyal to the king and the government-in-exile, such as former state officials, including teachers and postal workers, who had sworn their loyalty to the Yugoslav authorities and wanted to preserve their jobs after the war.

93. HR-DAST-23-507, Izvještaj, COZ iz Jugoslavije, March 1-31, 1944.

94. For example, a document of "suspicious people from Hvar for Bar" included the names of seven people, including those with family members who had been shot by the Partisans as Italian or Ustaša spies or as suspected sympathizers of Germans and Ustaše. HR-DAST-23-507, Popis sumnjih lica iz Hvara za Bari, Vis, January 26, 1944.

95. HR-DAST-23-507, no date.

96. HR-DAST-23-507, Saslušanja lica koja su napustila naše logore i prešla emigrantskoj vladi u Kairo. 
In the second half of 1945, well over 100 refugees left for El Arish. ${ }^{97}$ These departures were not without tensions. Thus, Nevena Dužević, for example, complained to the $\mathrm{COZ}$ that her son was attacked in the dining hall, that children pelted her tent with stones, and that her daughter was told that she was from a "Četnik tent," as she and her family were about to transfer to El Arish. ${ }^{98}$ Pragmatic reasons entered their considerations, however. When reviewing the personal biographies of those seeking to leave, recorded by the COZ, it is striking that many who had identified with the HSS before the war now described themselves as Yugoslav nationalists or pledged their support for the king. Considering that leaving the camp for El Arish was easier due to a political motivation rather than just hoping to seek a better future overseas, many might have invented or embellished their political motivations, considering that being a Royalist was a pedigree necessary to leave for El Arish. In other words, many might have chosen their loyalty to the young king out of pragmatism, rather than conviction, particularly since the return of the king might have still appeared plausible to many in Egypt.

Beyond the politically-organized opponents of the authorities in El Shatt, real or imagined, there was some broader level of anxiety about the emerging dominance of the Communist Party. This is best exemplified in this undated anonymous letter kept in the files of the COZ: "I joined NOP in Makarska. ... I am not a communist, but I am an opponent of the Ustaša, Četniks, etc. . . .Some things in the camp make me wonder. The secret service, monitoring at every step, being called a fifth columnist. Those who are not members [of the party] have no rights." 99

In April 1944, the COZ estimated that between 300 and 600 people could be counted among those dissatisfied. ${ }^{100}$ Later that year, the $\mathrm{COZ}$ distinguished between a small group of those who publicly agitated against the Partisans, and those who had a receptive audience among an "undecided group of around 1,000-1,200 people." ${ }^{101}$ Later, the estimate was even lower, suggesting that in the "worst case, we are talking about 200 cases out of 27,000 refugees, it is no political problem." 102 The British Ambassador to Yugoslavia considered the number to be considerably greater, numbering around 4,000 who opposed the communists. ${ }^{103}$ Whatever the number, the camp authorities never had to face a serious challenge to their dominance.

The COZ attributed the opposition to the influence of the royal government in exile in Cairo and thus could easily gain influence. They apparently spread stories of the difficult situation in the camp, as well as the dangers of the transport there. Stories of a better life in the other camps circulated and were spread by critics of the camp leadership, as the COZ noted the attraction of "the prospect of moving to the Četnik camp of King Petar and the government in exile, where living conditions are considerably better, where there is

97. HR-DAST-23-507, COZ, Upravno administrativni odjel, 21.9.1945, Logorski odbor 5. 98. HR-DAST-23-507, COZ, September 15, 1945.

99. HR-DAST-23-507, no date.

100. HR-DAST-23-507, Mate Barbić, Izvještaj, COZ, April 15, 1944.

101. HR-DAST-23-445, Izvještaj, COZ, August 10, 1944.

102. HR-DAST-23-507, COZ iz Jugoslavije, September 9, 1945.

103. Bratanić, Hrvatski zbjegovi u Egipat 1943-1946. 
no African desert sand, and where they might get paid. And supposedly the allied English would. . .even help in this."104

The camp administration kept a close eye on those whose loyalty they doubted, keeping reports of their meetings and activities, written by informants under code names such as "streljac" (shooter). These reports suggest that most merely voiced their opposition and dissatisfaction with the Partisans and the camp administration. A smaller group tried to recruit refugees to register for transfer to El Arish. The stories they told were like that of Jakov Griželj from Mostar, who sought to convince Jozo Vidis from Pelješac to leave. While the communists were killing their opponents en masse in Yugoslavia and he would be shot, he could instead move to America or South Africa with a good job and await the return of the king. While his claim that the king had 4,000 supports in El Shatt while Draža Mihailović had gathered 120,000 soldiers to take over Yugoslavia were fantastic in mid-1945, the survival and durability of Partisan rule in Yugoslavia was by no means settled and obvious to the refugees in Egypt. ${ }^{105}$

In February 1945, some opponents managed to make flyers on cigarette paper with the slogans "Death to Fascism and Communism-Long Live Democracy, Justice and Honor," for which informants suspected HSS supporters. ${ }^{106}$ The reach of such actions was limited, however, and as opponents could be transferred to El Arish, the camp administration had an easy and readily- available safety valve. ${ }^{107}$ Yet, the camps were not entirely self-contained. Opponents were sneaking out of the camp, sometimes swimming or taking a ferry across the nearby Suez Canal to travel to Cairo. ${ }^{108}$ Not all the illicit travel was based on political opposition: black marketers and prostitutes also sought to leave and enter camps without the Partisan guards noticing. ${ }^{109}$

Beyond those leaving for El Arish, many refugees sought not to return home. As the $\mathrm{COZ}$ gathered names, several hundred sought to leave for a third country. Some had American or other citizenship or were married to foreign citizens, mostly themselves Yugoslavs. The overwhelming majority of them came from the islands, in particular Vis. ${ }^{110}$ Some had families overseas in New Zealand, Australia, or the Americas and sought to begin a new life there. In 1945, the COZ presumably received some 243 requests to leave for overseas, 153 or 63 percent of which were granted. The most popular destinations were the United States and Australia. ${ }^{111}$

The COZ evaluated these requests not to return to Yugoslavia. As it had in 1944, it allowed people to leave if they gave political reasons, or had family

104. Izvještaj, COZ, April 15, 1944.

105. HR-DAST-23-507, Izvještaj, November 1-8, 1945.

106. HR-DAST-23-507, Izvještaj, February 10-26, 1945.

107. In October, it transferred six refugees to El Arish, including Petar Padovan, who had been active among the political opponents in previous months. HR-DAST-23-507, Movement Order, J.F. Conway, UNRRA, October 19, 1945.

108. For example, HR-DAST-23-507, Izvještaj, broj 7, March 28-April 8, 1945.

109. HR-DAST-23-507, Izvještaj, broj 8, April 8-20, 1945.

110. The COZ maintained several lists, including the names of over 400 people who did not want to return. HR-DAST-23-507, COZ, Upravni administravni odjel, 215/46, February 13, 1946.

111. HR-DAST-23-507, no date. 
connections overseas. However, the Committee also prohibited refugees from leaving when it thought that women had husbands or children had mothers back home in Yugoslavia. On this, the COZ noted that "[n]ot going into the reasons that force them to leave their husbands, we will consistently stand on the position that neither women nor children of our fighters can be allowed to be lost to our enemies. Not just politically, but on a human level, we are responsible for these children and their fathers and mothers will ask us tomorrow what we did."112

Over two years, the $\mathrm{COZ}$ and with it the Partisan movement created an experiment in Yugoslav state-building in El Shatt, complete with self-government, an educational and health systems, workshops, exhibitions, a cultural program, and media, combined with strong control over the lives of the refugees. The $\mathrm{COZ}$ was able to establish its authority due to a structure that was established prior to their arrival in Egypt and could not be easily challenged by the Allies. Once recognized, its efficiency won the-sometimes reluctant-admiration of the British and UNRRA authorities. It maintained support among the refugees through three strategies. First, it offered a comprehensive structure of camp life, from entertainment to education, which fully incorporated refugees and gave them an active stake in the new state-building project. The training, sports, and other activities sharply distinguished the camps managed by the $\mathrm{COZ}$ from other refugee camps. Second, it enforced tight ideological control that reduced the space for dissent. Finally, it provided controlled exit as an option for critics.

While the organization of the camp and the messages were carefully coordinated with the Partisan movement in Yugoslavia, the COZ operated largely autonomously in building this temporary extension of the Yugoslav state on the Sinai Peninsula.

Close to the end of the war, Mate Jakšić, the influential Yugoslav liaison officer, told the refugees who were to return home that

"the most solemn moment for the Yugoslav refugees in Egypt has now arrived. You were told you would go home when the Partisan army had liberated our country. That condition is now fulfilled. You left our country when the great fight was in progress but you are going back to a still greater fight-to struggle, rebuild, and reconstruct Yugoslavia.... Long live federated democratic Yugoslavia-long live Marshal Tito-long live our allies!"113

112. HR-DAST-23-507 COZ iz Jugoslavije, September 6, 1945.

113. UNA, S-1302-0000-8587 / 8589, Large Yugoslav contingent returns home, weekly bulleting, 38, April 25, 1945. 